\title{
Олександр Сінельніков
}

\section{ПІВНІЧНЕ ПРИЧОРНОМОР’Я В «GЕТІСА» ЙОРДАНА}

Анотація: Дана робота присвячена репрезентації основних даних, що стосуються Північного Причорномор'я у роботі готського історика епохи раннього середньовіччя - Йордана. Також зроблена спроба первинної інтерпретації иих звісток на основі історіографії питання. У праці присутній опис територій, що містять згадки гідронімів, топонімів, назв поселень та ін. Окрім того, стародавній автор відзначає велику кількість племен, що населяли ці території. Опис території Північного Причорномор'я і сусідніх регіонів, а також їх населення представлено в історичній ретроспективі. Крім, власне історії готів, "Getica», написана у середині VI cm. н.е., частково відображає подіï V, IV i I cm. до н.е. і римського періоду історії, до приходу готів на Північний Понт.

Ключові слова: Йордан, Північне Причорномор'я, історія готів, антична історія, етноніми, топоніми, гідроніми

Перш ніж перейти до розгляду власне тексту праці Йордана, необхідно, на наш погляд, висвітлити основні моменти, що стосуються життя самого автора, умов, місця та часу написання роботи, їі структуру. Детально зазначені вище моменти відображені у книзі «Йордан. Про походження і діяння Гетів (Getica)», в якій, окрім опублікованого перекладу тексту російською мовою, дано великі коментарі та пояснення Е.Ч. Скржинської. Ïї вступна частина якраз і розкриває питання життя Йордана і написання його праці. Зупинимося лише на найбільш важливих та інформативних даних, опустивши дискусії й аргументи, але ставлячи під сумнів деякі висновки автора, що обумовлюється. Крім того, у нашій роботі при аналізі основного тексту Йордана також використані коментарі Е.Ч. Скржинської.

У середині VI ст. народився твір, поміщений у рукописах під назвою «Про походження та діяння Гетів» («De origine actibusque Getarum»). Створив його автор, ім’я якого відоме $з$ самого тексту. Йордан (Jordanis) є одним з найвідоміших авторів епохи раннього європейського середньовіччя ${ }^{1}$.

31882 р. була прийнята штучна назва «Getica». Але ні повна, ні скорочена назва не розкриває всієї інформативності праці. Робота присвячена історії готів, але поєднує у собі важливі і, часом, унікальні дані про інші племена, процеси, що ілюструють їхні взаємини, про «вмираючу» Західну Римську імперію, про їі зіткнення з варварами 2 .

Перше, що хотілося б відзначити, це присутність у назві роботи етноніма гети. Йо-

\footnotetext{
"Сінельніков Олександр Сергійович - молодший науковий співробітник, Відділ археології Криму і ПівнічноЗахідного Причорномор'я Інституту археології Національної академії наук України (м. Одеса, Україна); ORCID: https://orcid.org/0000-0002-5352-7207; e-mail: sinelnikoff.senia@gmail.com

${ }^{1}$ Иордан. О происхождении и деянии гетов «Getica». Вступительная статья, перевод, комментарий Е.Ч. Скржинской. СПб: Изд. «Алетейя», 1997. С. 9.

${ }^{2}$ Ibidem.
} 
рдан називає готів гетами, помилково вважаючи перших нащадками останніх, або навмисно (що найбільш імовірно) представляючи історію готів більш давньою, що випливає 3 самого тексту. Вміщена у тексті інформація, яку автор приписує готам, відображає події середини V, IV і I ст. до н.е. та пов'язані, безпосередньо або побічно, з гетами.

Зі сторінок «Getica» ми можемо виділити певні звістки, хоч і нечисленні, які стосуються самого автора. Йордан був готом, швидше за все остроготом ${ }^{3}$ (остготом). Це твердження випливає із завершальної частини його роботи: «Але нехай ніхто не думає, що $九$, як ведучий своє походження від вищеназваного племені, додав щось на його користь проти того, що прочитав або дізнався» ${ }^{4}$. Крім того, він займав посаду нотарія, перебуваючи на службі у готського роду Амалів ${ }^{5}$. На сторінках праці Йордан повідомляє, що був нотарієм «до свого звернення» («ante conversionem meam»). Термін conversio у середньовічному вживанні мав два значення: вступ у чернецтво і вступ до групи осіб, які називаються religiosi, які залишаючись мирянами, дотримувалися деяких правил чернечого життя. Е.Ч. Скржинська вважає, що Йордан був саме religiosi. Равеннський географ, який писав не пізніше VIII ст., посилаючись на роботу Йордана, називає його тільки космографом або хроністом 6 .

3 приводу місця написання роботи, Е.Ч. Скржинська приходить до висновку, що Йордан не міг бути відірваним від подій в Італії, які детально описав, отже, текст був написаний у Равенні, між кінцем 550 і 1 квітня 551 рр. Такий висновок зроблено завдяки аналізу не тільки даної праці, а й «Historia Romana», що вийшла 3-під пера Йордана незабаром після завершення «Getica». У «Historia Romana» Йордан говорить про Юстиніана, як про правлячого імператора («regnat») вже 24 роки. Події обох робіт автор закінчує одним часом

Зі сторінок «Getica» ми дізнаємося про те, що Йордан пише її на замовлення, скорочуючи працю Кассіодора 3 такою ж назвою. Тобто, текст «Getica» є переказом давнішої роботи, завершеної до 533 р., яка не збереглася. Як зазначає Е.Ч. Скржинська, необхідність переписування праці Кассіодора виникла у результаті політичних подій в Італії того часу, а саме переваги сил у війні готів зі Східною Римською імперією у бік Юстиніана. Робота Кассіодора мала на меті звеличити готів та їх короля, прирівнявши їх історію до римської. Розстановка сил спонукала певні кола суспільства до зміни концепції праці Кассіодора та створення нової на її основі, яка б, не принижуючи готів, вихваляла б імперію Юстиніана. Саме завдяки своїй політичній спрямованості, як вважає Е.Ч. Скржинська, праця Кассіодора не збереглася ${ }^{8}$.

Основною темою роботи є історія готів, що розділилися на два племені: остготів і вестготів. Умовно працю можна розділити на три розділи:

1. Історія готів, які вийшли зі Скандинавії та просунулися на береги Чорного моря, аж до нашестя гунів;

\footnotetext{
${ }^{3}$ Ibid. C. 10.

${ }^{4}$ Get., $§ 316$ (тут і далі вказані загальноприйняті скорочення для письмових джерел античного та ранньосередньовічного періодів)

${ }^{5}$ Иордан. О происхождении и деянии гетов «Getica». C. 13.

${ }^{6}$ Ibid. C. 15-22.

${ }^{7}$ Ibid. C. 29-31.

${ }^{8}$ Ibid. C. 31.
} 
2. Історія вестготів, які вийшли з Північного Причорномор'я та рушили на Захід;

3. Історія остготів, які пізніше залишили цю територію й осіли в Італії9

Крім цих, основних віх, «Getica» насичена відступами (опис територій, легенди, сусідні народи). Важливими $є$ описи територій, по яких проходили, і розташування на них племен, з якими воювали готи у той чи інший проміжок часу. Найбільш цікавим для нас $\epsilon$ опис Північного Причорномор'я і сусідніх з ним регіонів".

Виводячи готів зі Скандзи (Скандинавського півострова), Йордан повідомляє про їх переселення на територію Скіфії:

«У пошуках зручних областей і відповідних місиь (для розселення) він (Філімер, король готів) прийшов у землі Скіфії, які їхньою мовою називалися Ойум» ${ }^{10}$.

Далі автор дає опис цієї землі:

«Скіфія погранична із землею Германії аж до того місия, де народжується річка Істр і простягається Мурсіанське озеро; вона тягнеться до річки Тіри, Данастра та Вагосоли, а також до великого того Данапра і до гори Тавра - не тієї, що в Азії, а власної, тобто скіфської, - по всій прилеглій до Меотіди місцевості іза Меотіду, через Босфорські протоки до Кавказьких гір і річки Араксу; потім вона [Скіфія], загнувшись у ліву сторону, за Каспійське море..., схиляється до області гунів і відступає до албанів і серів... Скіфія... має зі сходу серів, що живуть у самого ї початку на березі Каспійського моря; із заходу германців і річку Вістулу; з півночі вона охоплюється океаном, з півдня - Персією, Албанією, Іберією, Понтом і нижньою течією Істра, який називається також Данубієм від гирласвого до витоку»"1.

На даному пасажі слід зупинитися докладніше. На заході автор доводить Скіфію до кордонів з Германією по річці Вістулі (Віслі), витоків Істра-Данубія (Дунаю) і Мурсіанського озера. Не викликає сумніву той факт, що Йордан перебільшує, доводячи Скіфію до витоків Дунаю, але у даному випадку слід зробити застереження. У тексті Йордана вживаються дві назви Дунаю: Істр і Данубій. Згадують дві назви і Страбон ${ }^{12}$, Пліній ${ }^{13}$, пояснюючи це тим, що від своїх витоків до певного місця Дунай має одну назву - Данубій, далі до гирла - Істр. Такої ж традиції дотримується і Йордан. Виходить, що в уяві автора Дунай іменувався Істром, починаючи приблизно з території, де у нього впадала Тиса, а праворуч - Сава ${ }^{14}$.

Е.Ч. Скржинська у своїх коментарях ілюструє широку дискусію щодо локалізації Мурсіанского озера ${ }^{15}$. Частина дослідників стверджує, що Мурсіанським озером Йордана є сучасне озеро Балатон в Угорщині, болота поблизу гирла річки Драви, Нейзідлерське озеро й ін. Е.Ч. Скржинська схиляється до думки, що озеро Балатон (Йордан згадує озеро Пелсо - Пелсойс - Пелсод двічі ${ }^{16}$ ) найбільше підходить під описаний Йорданом водний

\footnotetext{
${ }^{9}$ Ibid. C. 52.

“ Очікувані місця розташування об'єктів і розселення племен винесені на рисунок 1.

${ }^{10}$ Get., $§ 27$.

${ }^{11}$ Ibid. § 30-32.

${ }^{12}$ Geogr., VII, 3, 13.

${ }^{13}$ Plin., IV, 78-82.

${ }^{14}$ Иордан. О происхождении и деянии гетов «Getica». C. 192.

${ }^{15}$ Ibid. C. 209-213.

${ }^{16}$ Get., $\S \S 268,274$.
} 
об’єкт. Повторно він згадується при описі територій розселення склавенів. У зв'язку з цим, місцем розташування озера може бути Нижнє Подунав'я. Суперечливість локалізації згаданого Йорданом гідроніма підтверджується тим, що у першому уривку Мурсіанське озеро «тягнеться» там «де народжується річка Істр», у другому ж, «Склавени живуть від міста Новієтуна й озера, що назване Мурсіанським, до Данастра, і на північ - до Віскли...» ${ }^{17}$.

Місто Новієтун у Йордана може бути ототожнене з римським містом Новіодунум, розташованим на правому березі Нижнього Дунаю. Щодо цього Е.Ч. Скржинська стверджує, що Новієтуном Йордана є Нівеодун поблизу Сави, нижче Любляни, на римській дорозі від Дунаю до Аквілеї і в Італію ${ }^{18}$ (на кордоні Верхньої Паннонії та Лібурнії, у західній частині Ілліріка). При описі розселення склавенів далі згадується Данастр (Дністер), а антів - Данапр (Дніпро), що наштовхує на думку про розселення цих племен на територіях ближче до нижніх течій зазначених річок. Можливо, при описі розселення склавенів Йордан вказав дві крайні південні точки займаної ними території (Новієтун і Мурсіанське озеро), так як далі вказані північна (Вістула) і західна (Данастр) іï межі. Тоді ототожнення Мурсіанського озера з водним об'єктом десь у сучасній Угорщині буде більш прийнятним. При цьому території їх розселення мали обтікати Дакію, заселену гепідами, із заходу, півночі та сходу, і не виходити на правий берег Дунаю, який був південним природним кордоном. Якщо Йордан поміщає у Скіфії першими із заходу гепідів, ${ }^{19}$ то розташовувати склавенів на захід від цього племені не варто, тому що автор послідовний у перерахуванні географічних об'єктів і племен із заходу на схід. 3 іншого боку, такий великий римський пункт, як Мурса, від назви якого могло піти найменування озера, перебував при впадінні річки Драва в Дунай у Нижній Паннонії (східний Іллірікум). Місцезнаходження Мурси та Невіодунума і наштовхнуло дослідників на думку про розташування Мурсіанського озера десь у районі цих пунктів. Стверджувати, що Йордан назвав відоме озеро Пелсо (нинішній Балатон), згадане ним же у тексті, Мурсіанським можна лише з певною часткою сумніву.

У своєму описі Скіфської землі Йордан згадує й інші об’єкти. Інтерес викликає вказівка річок Тіри та Данастра як двох різних. Відомо, що Тіра і Данастр - дві назви сучасного Дністра, які фігурують обопільно і в інших джерелах, наприклад, у Амміана Марцелліна $^{20}$, але для позначення однієї і тієї ж річки та позначаючи місто Тіру. Відсутність при перерахуванні міст Північного Причорномор'я Тіри наштовхує на думку, що Йордан переплутав назву міста та річки, згадавши Тіру та Данастр як гідроніми, але це лише припущення. Далі у тексті відзначена річка Вагосола. Даний гідронім невідомий $з$ інших джерел, але перерахування Йорданом річок із заходу на схід дає підставу припустити, що це назва Південного Бугу, що іменувався в античності Гіпаніс ${ }^{21}$. Цікаво, що при описі річки Данапр (сучасний Дніпро) Йордан згадує два міста у його гирлі, - Калліпід і Гіпанніс, -

\footnotetext{
${ }^{17}$ Ibid. § 35 .

${ }^{18}$ Иордан. О происхождении и деянии гетов «Getica». С. 209.

${ }^{19}$ Get., $\$ 33$

${ }^{20}$ Amm. Mars., XXII, 8, 41.

${ }^{21}$ Иордан. О происхождении и деянии гетов «Getica». C. 194.
} 
між якими Дніпро впадає у море ${ }^{22}$. Відома історику і назва Борисфен ${ }^{23}$. Відомий і Ахіллів острів поблизу його гирл ${ }^{24},-$ «Ахіллів дром».

Решта, згаданих Йорданом при описі Скіфії, географічних об’єктів не викликають питань щодо ототожнення їх з сучасними та відомими з інших письмових джерел (Гора Тавра - Кримські гори, Меотіда - Азовське море та Приазов'я, Боспорські протоки - Керченська протока і т.д.).

Далі у тексті Йордан перераховує міста Скіфії: «3 того свого боку, яким Скіфія досягає Понтійського узбережжя, вона охоплена відомими містами; ие - Борисфеніда, Ольвія, Калліполіда, Херсона, Феодосія, Кареон, Мірмікій $і$ Трапезунта» ${ }^{25}$. Першим кидається в очі перерахування Борисфеніди й Ольвії як різних міст. Йордан користувався роботами Страбона ${ }^{26}$, Птоломея ${ }^{27}$, Помпонія Мели ${ }^{28}$, що й могло спонукати до згадки двох назв одного міста. Знову ж, автор згадує міста із заходу на схід, завдяки чому можна припустити, що Калліполідою Йордан назвав грецький Калос Лімен, видозмінивши або спотворивши назву. Таке найменування співзвучно з племенем калліпідів, відомих 3 часів Геродота 29 . Ототожнення ж інших пунктів (Херсона - Херсонес, Феодосія, Мірмікій - у районі Керчі) ${ }^{30}$ крім Кареона, питань не викликає. Вище у тексті ми вже згадали про відсутність Тіри при перерахуванні міст Понтійського узбережжя.

Крім цього, Йордан повідомляє, що «Посередині Скіфї̈ є місце, яке розділяє Азію та Європу одну від одної; ие - Рифейські гори, які виливають найширший Танаіс, що впадає у Меотіду». Даний пасаж зі згадуванням місця поділу Європи та Азії є традиційним для багатьох античних авторів (Помпоній Мела ${ }^{31}$, Пліній ${ }^{32}$, Амміан Мірцеллін та ін.) ${ }^{33}$. Розміщення у тексті Меотіди не вимагає спеціальних пояснень.

Подальші описи присвячені племенам, розселеним у Скіфії: «...nершим із заходу живе плем'я гепідів, оточене великими та славними річками; на півночі і північному заході по його областям протікає Тізія; $з$ півдня ж ию область відсікає сам великий Данубій, а зі сходу Флютавзій... Між иими річками лежить Дакія... починаючи від місия народження річки Вістули, на безмежних просторах розташувалося багатолюдне плем'я венетів. Хоча їх найменування тепер змінюються відповідно до різних родів і місцевостей, все ж переважно вони називаються склавенами й антами» ${ }^{34}$. Даний уривок присвячений теритоpiї розселення гепідів, яких Йордан поміщає у Дакії, обмежуючи ї̈ річками Тізією (Тисою), Флютавзієм (Олтом) і Дунаєм. Крім того, автор повідомляє про плем'я венетів і їх розподіл на антів і склавенів.

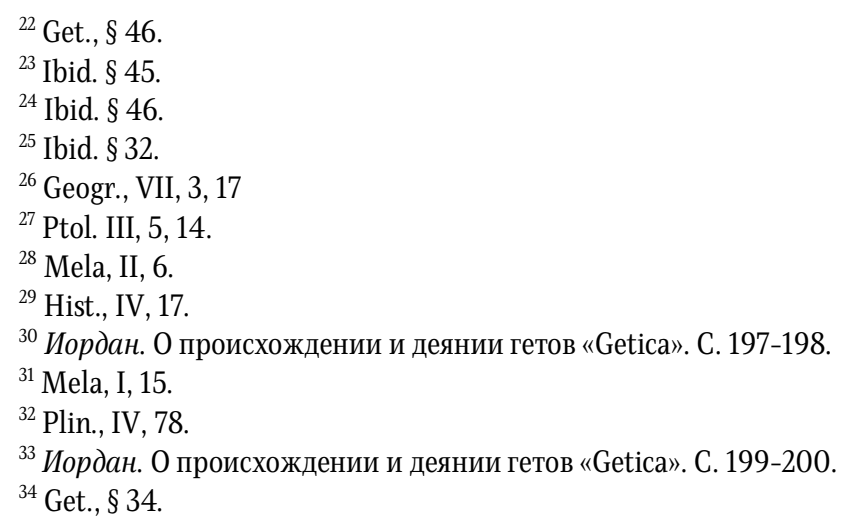


Нижче говориться про те, що «Склавени живуть від міста Новієтуна й озера, що назване Мурсіанським, до Данастра і на північ - до Віскли; замість міст у них болота та ліси. Анти ж - найсильніші з обох племен - поширюються від Данастра до Данапра, там де Понтійське море утворює вигин...» ${ }^{35}$. Ми вже торкалися питання ототожнення Мурсіанського озера. Виходячи з даного повідомлення, воно розташовувалося десь у низов'ях Дунаю, але говорити про це ствердно все ж не варто. В іншому ж Йордан досить чітко зазначає, що склавени займають територію між Дунаєм і Дністром аж до верхів'я Вісли, анти - територію між Дністром і Дніпром. Цікаво, що при описі розселення антів, автор акцентує увагу на пониззі Дніпра «там, де Понтійське море утворює вигин...», що і наштовхує на думку про присутність зазначених племен ближче до нижніх течій позначених річок.

Певного роду висновком переданих Йорданом відомостей про Скіфію та племена, що її заселяли, є наступний пасаж: «...nерше розселення готів було у Скіфській землі, поблизу Меотійського болота; друге - у Мізї, Фракії та Дакії; третє - на Понтійському морі, знову у Скіфіі...» ${ }^{36}$. У попередній частині Йордан описав племена, що заселяли Скіфію, ймовірно, під час написання його роботи (венети, склавени, анти). Тут же він говорить про розселення готів по означеному регіоні після їх приходу до берегів Чорного моря. Таким чином, автор змалював у своїй роботі не тільки історію розселення готів по Північному Причорномор'ю, а й історичний зріз заселеності цих земель іншими племенами після них.

Крім зазначеного вище, у тексті Йордана ми зустрічаємо повідомлення, що стосується відомих нам з інших джерел племен сарматів. «Цю Готію, яку предки називали Дакією і яка тепер, як ми сказали, іменується Гепідією, тоді обмежували зі сходу ароксолани, із заходуязиги, з півночі сармати та бастерни, з півдня - річка Данубій. Язиги ж від ароксолан відокремлюються тільки річкою Алут» ${ }^{37} .3$ наведеного уривка випливає, що територію описаної Йорданом Дакії із заходу, півночі та сходу обмежували язиги, сармати та бастерни, ароксолани відповідно. Переселення язигів в Угорську пушту датується першою половиною I ст. ${ }^{38}$ Саме 3 цією територією пов'язана у подальшому їх історія і саме про неї повідомляє Йордан у даному пасажі. Роксолани мали місцем розселення спочатку регіони лісостепової Молдови, потім Буджак приблизно з першої чверті II ст. аж до «Скіфських воєн» ${ }^{39}$. Області бастарнів (бастернів) зазвичай розташовують на північно-східних схилах Карпат: саме таке розселення і вказане Йорданом, а відомі вони і для II ст. (союз з маркоманнами), і для III ст. (союз з готами) ${ }^{40}$. Подібне розселення племен може датуватися періодом, починаючи з середини I століття, коли язиги переселяються на Тиську рівнину, до «Скіфських» або «Готських» воєн, після яких змінюється розміщення багатьох племен як на північ, так і на південь від Дунаю. В уривку, присвяченому опису гунів, Йордан згадує і про аланів, які перебували у Приазов'ї та підкорених першими під час свого нашестя.

\footnotetext{
${ }^{35}$ Ibid. $\S 35$.

${ }^{36}$ Ibid. $\$ 38$.

${ }^{37} \mathrm{Ibid}$. $\$ 74$.

${ }^{38}$ Дзиговский А.Н. Очерки истории сарматов Карпато-Днестровских земель. Одесса. 2003. С. 86.

${ }^{39}$ Ibid. C. 150-156.

${ }^{40}$ Иордан. О происхождении и деянии гетов «Getica». С. 242.
} 
Повідомляє Йордан і про інші племена: «...nриєднавши до них [до карпів] готів і певкінів з острова Певкі, який лежить при гирлах Данубію, що впадає у Понт...» ${ }^{41}$. Карпи відомі і за іншими джерелами (Птолемей, Зосим) $)^{42}$. Причому часто вони грали не останню, а іноді й провідну роль у військових конфліктах з Імперією ${ }^{43}$. Про певкінів 3 острова Певкі повідомляє Страбон ${ }^{44}$, Птолемей ${ }^{45}$, слідом за якими Йордан поміщає дане плем'я у гирлі Дунаю ${ }^{46}$.

По мірі висвітлення Йорданом політичних і військових подій, пов'язаних з готами та їх взаємовідносинами з оточуючими племенами й Імперією, ми зустрічаємо у тексті дані, що побічно розкривають питання про «Скіфські війни». Автор говорить про походи готів у союзі з іншими племенами проти Римської імперії, про війни з варварськими племенами, про нашестя гунів і про переселення з Північного Причорномор'я на захід спочатку везеготів (вестготів), потім і остроготів (остготів). У ході цього оповідання закінчуються згадки Йорданом території Північного Причорномор'я і подій, з ним пов'язаних.

Таким чином, з тексту «Getica», присвяченого, у більшості, «славній» історії готів, ми маємо можливість почерпнути досить великі дані, що стосуються різних періодів істоpiї Північного Причорномор'я, починаючи (якщо відкинути легендарні, напів достовірні вставки) від заселення його готами до середини VI ст. н.е., тобто часу написання праці Йорданом. Основною метою нашої роботи було об'єднання відомостей, що стосуються опису території та населення Північного Причорномор'я. Завдяки аналізу джерела та коментарів до нього, вдалося зібрати воєдино дані для цього і сусідніх регіонів, що представляють історичний зріз як їх топоніміки та гідроніміки, так і етнічної складової римського та пізньоантичного часу, аж до середини VI ст. Дотримуючись античної писемної традиції, Йордан згадує різні назви, деякі з яких, з певними видозмінами, використовуються й до сьогодні.

\section{Alexander Sinelnikov}

\section{Northern Black Sea Region in «Getica» Of Jordan}

Resume: This work is devoted to the representation of basic data concerning the Northern Black Sea coast in the work of the Gothic historian of the early Middle Ages - Jordan. Also, an attempt was made to initially interpret this news on the basis of the historiography of the issue. The work contains descriptions of territories, including the mention of hydronyms, toponyms, names of settlements, etc. In addition, the ancient author notes a large number of tribes that inhabited these territories. Trying to present the history of his people more ancient, the Jordan, intentionally or unconsciously, connects the Goths with the Getae. Due to this and

\footnotetext{
${ }^{41}$ Get., $\S 91$

${ }^{42}$ Иордан. О происхождении и деянии гетов «Getica». С. 251.

${ }^{43}$ Дзиговський А.Н. Указ. соч. С. 162, 169-176.

${ }^{44}$ Geogr., VI, 3, 17

${ }^{45}$ Ptol. III, 10, 4.

${ }^{46}$ Иордан. О происхождении и деянии гетов «Getica». C. 252.
} 
other factors, a description of the territory of the Northern Black Sea region and neighbouring regions, as well as their population, is presented in a historical retrospective. In addition, the actual story is ready, "Getica», written in the middle of the VI century. BC, partially reflects the events of the V, IV and I centuries. BC. and the Roman period of history, before coming ready to the North Pontus. It should be noted, the attraction of the work of Jordan to the ancient written tradition. The historical environment of the region is valuable for studying, first of all, its Roman and Late Antique history.

Keywords: Jordan, Northern Black Sea region, Goths history, ancient history, ethnonyms, toponyms, hydronyms 


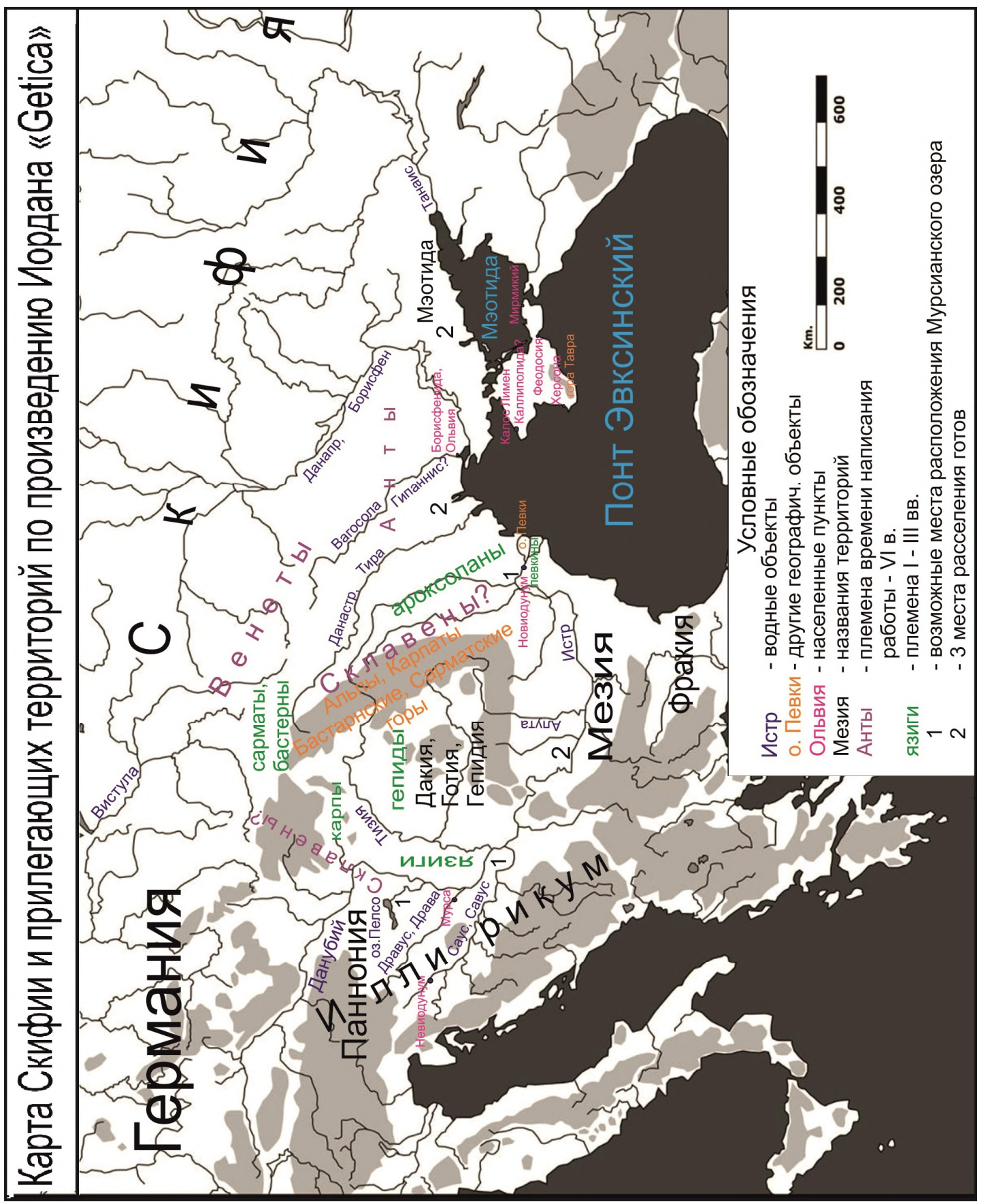

